\title{
Nitro-Oleic Acid Regulates Endothelin Signaling in Human Endothelial Cells
}

\author{
Emilia Kansanen, Suvi M. Kuosmanen, Anna-Kaisa Ruotsalainen, Heidi Hynynen, and \\ Anna-Liisa Levonen
}

A.I. Virtanen Institute for Molecular Sciences, University of Eastern Finland, Kuopio, Finland (E.K., S.M.K, A.-K.R., H.H., A.-L.L.)

Received June 29, 2017; accepted August 2, 2017

\begin{abstract}
Nitro-fatty acids are reactive signaling mediators that are formed when unsaturated fatty acids react with nitric oxide or nitric oxidederived species. Nitro-fatty acids can modify specific signaling pathways via post-translational modifications of Cys residues in key regulatory proteins. One of the signaling cascades activated by nitro-fatty acids is the Keap1-Nrf2 pathway. We have previously studied the effects of nitro-oleic acid $\left(\mathrm{OA}-\mathrm{NO}_{2}\right)$ on the human endothelial cell transcriptome. We observed that endothelin receptor $\mathrm{B}$ [ET-B (gene name EDNRB)], the receptor mediating the vasodilatory effects of endothelin-1 (ET-1) is induced by $\mathrm{OA}-\mathrm{NO}_{2}$. Inasmuch as ET-1 is one of the key regulators of vascular tone, we chose to examine in more detail the effect of $\mathrm{OA}-\mathrm{NO}_{2}$ on endothelin signaling in human endothelial cells. Nrf2 was found to regulate the $\mathrm{OA}-\mathrm{NO}_{2}$-induced transcription of ET-B in
\end{abstract}

human and mouse endothelial cells. Furthermore, chromatin immunoprecipitation analysis revealed that $\mathrm{OA}-\mathrm{NO}_{2}$ increased the binding of Nrf2 to an antioxidant response element in the enhancer region of the EDNRB gene. In addition, we show that the overexpression of both $\mathrm{OA}-\mathrm{NO}_{2}$ and Nrf2 substantially decreased and that Nrf2 silencing increased the ET-1 concentration in the culture media of endothelial cells. The change in the extracellular ET-1 concentration was dependent on ET-B receptor expression. These data suggest that $\mathrm{OA}-\mathrm{NO}_{2}$ modulates endothelin signaling by increasing Nrf2-dependent expression of the ET-B receptor in endothelial cells, which in turn mediates the decrease in extracellular ET-1 concentration. Based on these results, we propose that $\mathrm{OA}-\mathrm{NO}_{2}$ and Nrf2 may alleviate the vasoconstrictive effects of ET-1 by removing it from the circulation.

\section{Introduction}

Nitro-fatty acids are endogenous signaling molecules formed in vivo when unsaturated fatty acids react with nitric oxide (NO) and NO-derived species (Schopfer et al., 2011). Nitro-fatty acids are generated in inflammatory conditions including ischemic preconditioning (Nadtochiy et al., 2009) and myocardial ischemia/reperfusion (Rudolph et al., 2010b). Nitro-fatty acids can alter specific signaling pathways by Michael addition with nucleophiles of biologic targets. They can modulate regulatory protein functions via post-translational modification of susceptible nucleophilic amino acids, such as Cys (Batthyany et al., 2006; Baker et al., 2007; Schopfer et al., 2010; Kansanen et al., 2011). Nitro-oleic acid $\left(\mathrm{OA}-\mathrm{NO}_{2}\right)$ is beneficial in murine models of vascular disease (Cole et al., 2009; Rudolph et al., 2010a), type 2 diabetes (Schopfer et al., 2010), and both myocardial (Rudolph et al., 2010b) and renal (Wang et al., 2010) ischemia reperfusion injury. In addition, $\mathrm{OA}-\mathrm{NO}_{2}$ has

This study was financially supported by the Academy of Finland (E.K. and A.-L.L.), the Sigrid Juselius Foundation (A.-L.L.), the Finnish Foundation for Cardiovascular Research (A.-L.L.), the Orion-Farmos Foundation (E.K.), the Emil Aaltonen Foundation (E.K.), and the Finnish Cultural Foundation (E.K.). https://doi.org/10.1124/mol.117.109751. antihypertensive effects in angiotensin II-induced mouse hypertension (Zhang et al., 2010), and it also has antihypertensive signaling actions via inhibition of the enzymatic activity of epoxyeicosatrienoic acid hydrolyzing soluble epoxide hydrolase by adduction to Cys521 in the vicinity of its catalytic center (Charles et al., 2014).

Nuclear factor-E2-related factor 2 (Nrf2) is a transcription factor that regulates multiple antioxidant and cytoprotective genes. The well-known Nrf2 target genes that are often used as markers for Nrf2 activation are heme oxygenase-1 (HMOX1), glutamate cysteine ligase, and NADPH quinone oxidoreductase-1 (Kwak et al., 2003; Lee et al., 2003). Kelchlike ECH-associated protein 1 (Keap1) is a redox-regulated protein that inhibits the nuclear translocation of Nrf2 by mediating the rapid ubiquitination and degradation of Nrf2 in nonstimulated, basal conditions (Zhang and Hannink, 2003). In oxidative or electrophilic stress, specific Cys residues in Keap1 are modified, which results in a conformational change in Keap1 leading to the escape of Nrf2 from the Keap1dependent degradation pathway and translocation to the nucleus. In the nucleus, Nrf2 binds to the antioxidant response element (ARE) located in the enhancer region of its

ABBREVIATIONS: AdNrf2, nuclear factor-E2-related factor overexpressing adenovirus; ANOVA, analysis of variance; ARE, antioxidant response element; ChIP, chromatin immunoprecipitation, ET-1 (gene name EDN1), endothelin-1; ET-A (gene name EDNRA), endothelin receptor A; ET-B (gene name EDNRB), endothelin receptor B; GCLM, glutamate-cysteine ligase modifier subunit; HAEC, human aortic endothelial cell; HASMC, human aortic smooth muscle cell; HMOX1, heme oxygenase-1; HUVEC, human umbilical vein endothelial cell; Keap1, Kelch-like ECH-associated protein 1; NO, nitric oxide; Nrf2, nuclear factor-E2-related factor 2; $\mathrm{OA}-\mathrm{NO}_{2}$, nitro-oleic acid; PAH, pulmonary arterial hypertension; PBS, phosphate-buffered saline; qPCR, quantitative real-time polymerase chain reaction; RT, room temperature; siRNA, small interfering RNA. 
target genes, thus driving their expression (Kansanen et al., 2012). We have previously discovered that $\mathrm{OA}-\mathrm{NO}_{2}$ induces Nrf2-dependent cytoprotective gene expression (Kansanen et al., 2009), which involves the direct modification of Keap1 Cys residues Cys38, Cys226, Cys257, Cys273, Cys288, and Cys489. Of these Keap1 Cys residues, Cys273 and Cys288 were found to be functionally most important in the activation of Nrf2 (Kansanen et al., 2011). Furthermore, in a genomewide analysis of Nrf2-dependent and -independent effects of $\mathrm{OA}-\mathrm{NO}_{2}$, we found that the expression of endothelin receptor $\mathrm{B}$ [ET-B (gene name $E D N R B$ )] was induced by $\mathrm{OA}-\mathrm{NO}_{2}$ and repressed by Nrf2 small interfering RNA (siRNA) in human endothelial cells (Kansanen et al., 2009). ET-B is a receptor for endothelin-1 [ET-1 (gene name $E D N 1$ )], which was first identified as a potent vasoconstrictor, but it is now recognized that ET-1 can also function as a vasodilator, depending on the receptor being activated. In the vasculature, endothelin receptor A (ET-A, gene name EDNRA) is present predominantly in smooth muscle cells, whereas the ET-B receptor is located in endothelial cells. However, a subfamily of ET-B receptors is also present in vascular smooth muscle cells. In smooth muscle cells, the activation of both ET-A and ET-B induces vasoconstriction, but the stimulation of ET-B receptors in endothelial cells promotes vasodilatation (Schneider et al., 2007). In addition, ET-B functions as a clearance receptor to remove ET-1 from the circulation (Kelland et al., 2010a).

Inasmuch as ET-1 is one of the key regulators of vascular tone, we chose to examine in more detail the effect of $\mathrm{OA}-\mathrm{NO}_{2}$ on endothelin signaling in human endothelial cells. We show that the upregulation of ET-B receptor by $\mathrm{OA}-\mathrm{NO}_{2}$ is tightly regulated by Nrf2 in human and mouse endothelial cells. In addition, in silico screening identified two putative ARE sites residing on the active enhancer region at the $E D N R B$ gene locus. In response to $\mathrm{OA}-\mathrm{NO}_{2}$, chromatin immunoprecipitation (ChIP) analysis revealed an increase in binding of Nrf2 to an ARE site located 5253 base pairs upstream of the transcription start site of the EDNRB gene. In addition, we show that both $\mathrm{OA}-\mathrm{NO}_{2}$ and $\mathrm{Nrf} 2$ overexpression substantially decreased and Nrf2 silencing increased the ET-1 concentration in the cell culture media. The decrease in the extracellular ET-1 concentration was dependent on ET-B receptor expression. These data suggest that Nrf2 regulates the $\mathrm{OA}-\mathrm{NO}_{2}$-induced transcription of ET-B, which may lead to the clearance of ET-1 from the circulation.

\section{Materials and Methods}

Reagents. OA-NO $\mathrm{N}_{2}$ was prepared as previously described (Woodcock et al., 2013). The synthetic nitration product used in the study was an equimolar mixture of 9- and 10-nitro-octadec-9-enoic acid. BQ-788 was from Sigma-Aldrich (St. Louis, MO).

Cell Culture. Human umbilical vein endothelial cells (HUVECs) were isolated from umbilical cords obtained from the maternity ward of the Kuopio University Hospital by the approval of the Kuopio University Hospital Ethics Committee. Each mother signed an informed consent form. HUVECs were cultured as previously published (Levonen et al., 2004). Cells from multiple donors were used for experiments at cell passages 4-6. Human aortic endothelial cells (HAECs) were obtained from Lonza (Bergisch Gladbach, Germany) and were cultured as reported in the study by Kivelä et al. (2010). Cells from a single donor were used at passages 8-10. Human aortic smooth muscle cells (HASMCs) were purchased from Cascade Biologics (Portland, OR) and cultured in 231 medium supplemented with
Smooth Muscle Cell Growth Supplement (Cascade Biologics). Cells were from a single donor and were used at passages 10-12. Mouse endothelial cells were isolated as described in the study by Zhang et al. (2009), with modifications. The lungs and hearts from 10-weekold wild-type or Nrf2 knockout mice were removed under surgical anesthesia and collected in a tube containing cold base medium (Dulbecco's modified Eagle's medium with $20 \%$ fetal bovine serum, $20 \mathrm{mM}$ HEPES, $50 \mathrm{U} / \mathrm{ml}$ penicillin, and $50 \mu \mathrm{g} / \mathrm{ml}$ streptomycin). Tissues were washed with $1 \times$ phosphate-buffered saline (PBS) and were finely minced and digested using type II collagenase (Worthington Biochemical Corp., Lakewood, NJ) for $1 \mathrm{~h}$ at $37^{\circ} \mathrm{C}$ with gentle agitation. Digested tissues were passed through a 20 -gauge needle 10-15 times and were then filtered through a $70-\mu \mathrm{m}$ cell strainer. The digested filtrate was centrifuged, and the pellet was washed twice and resuspended in base medium. The filtrate was then incubated for $30 \mathrm{~min}$ at $+4^{\circ} \mathrm{C}$ with $25 \mu \mathrm{g}$ of antimouse CD31 antibody (BD Pharmingen, Minneapolis, MN) after which $100 \mu \mathrm{l}$ of magnetic microbeads (Miltenyi Biotech, Bergisch Gladbach, Germany) was added to the mixture and incubated at room temperature (RT) for $15 \mathrm{~min}$. Cells with beads attached were collected using a MACS Separation Column (Miltenyi Biotech) and washed three times with PBS. Washed cells were collected and plated in full medium (base medium with 1/100 nonessential amino acid, 1/100 sodium pyruvate, $1 \mathrm{mM}$ L-glutamine, $0.1 \mathrm{mg} / \mathrm{ml}$ endothelial mitogen, and $0.1 \mathrm{mg} / \mathrm{ml}$ heparin) tissue culture plates that had been precoated with $10 \mu \mathrm{g} / \mathrm{ml}$ fibronectin (Sigma-Aldrich) in PBS. After $24 \mathrm{~h}$, nonattached cells and excess beads were removed, and fresh medium was added. Cells were further purified by repeating the protocol with anti-mouse CD102 antibody (BD Pharmingen) and by growing them in full medium. For experiments, cells were cultured in EBM Endothelial Medium supplemented with the EGM Bullet Kit (Lonza). Cells were pooled from five mice and were used for experiments at passages 4-6. Animal work was approved by the National Experimental Animal Board of Finland and carried out following the guidelines from Directive 2010/63/EU of the European Parliament on the protection of animals used for scientific purposes.

Western Blot. HUVECs and HAECs were treated with $5 \mu \mathrm{M}$ OA-NO $\mathrm{N}_{2}$ for 2 or $4 \mathrm{~h}$, after which cells were collected in MNase buffer (10 mM Tris, pH 7.4, $10 \mathrm{mM} \mathrm{NaCl}, 5 \mathrm{mM} \mathrm{MgCl}_{2}, 0.1 \% \mathrm{NP} 40$, and protease inhibitors) to extract the nuclear fraction. The extracted nuclei were lysed, and the nuclear proteins were electrophoresed on a Tris/glycine SDS-polyacrylamide gel, and transferred to nitrocellulose membrane. The primary antibodies used for detection were rabbit polyclonal anti-Nrf2 (Santa Cruz Biotechnology, Dallas, TX), rabbit polyclonal anti-Lamin B1 (Abcam, Cambridge, UK). Blots were visualized using Cys5-conjugated secondary antibodies with ChemiDoc (Bio-Rad, Hercules, CA) scanner. Protein expression was quantified with ImageLab Software (version 5.2.1; Bio-Rad).

siRNA Transfections. siRNA oligonucleotide targeting Nrf2 and a nonspecific RNA control were obtained from Invitrogen (Carlsbad, CA). HUVECs or HAECs were seeded on six-well plates at a density of 150,000 cells/well. Cells were allowed to adhere for $24 \mathrm{~h}$, after which they were transfected with $50 \mathrm{nM}$ siRNA oligonucleotides using Oligofectamine (Invitrogen). Twenty-four hours after transfection, cells were treated with $\mathrm{OA}-\mathrm{NO}_{2}$ for quantitative real-time polymerase chain reaction (qPCR).

Adenoviral Overexpression. Cloning and production of Nrf2 overexpressing adenovirus (AdNrf2) were performed as described previously (Levonen et al., 2007). A multiplicity of infection of 100 was used for experiments.

RNA Isolation and qPCR. Cells were collected and RNA extracted with TRI Reagent (Sigma-Aldrich) according to manufacturer instructions. For the cDNA synthesis, $1 \mu \mathrm{g}$ of total RNA was used with random hexamer primers (Promega, Madison WI) and Moloney murine leukemia virus reverse transcriptase (Finnzymes, Espoo, Finland). The relative expression levels were measured according to the manufacturer protocol with qPCR (StepOnePlus Real-Time PCR systems; Applied Biosystems, Foster City, CA) using specific assayson-demand (Applied Biosystems) target mixes. The expression levels were normalized to $\beta 2$-microglobulin or to glyceraldehyde-3-phosphate 
dehydrogenase expression and presented as the fold change in the expression versus control.

ChIP. ChIP analysis was performed as previously described (Kansanen et al., 2011). Briefly, HUVECs were treated with $5 \mu \mathrm{M}$ $\mathrm{OA}-\mathrm{NO}_{2}$ for $30 \mathrm{~min}$ to $2 \mathrm{~h}$. Nuclear proteins were crosslinked to DNA by adding formaldehyde directly to the medium to a final concentration of $1 \%$ for $10 \mathrm{~min}$ at RT on a rocking platform. Crosslinking was stopped by adding glycine to a final concentration of $0.125 \mathrm{M}$ for $5 \mathrm{~min}$ at $\mathrm{RT}$ on a rocking platform. Nuclei were extracted by scraping the cells to $1 \mathrm{ml}$ of MNase buffer ( $10 \mathrm{mM}$ Tris, $\mathrm{pH} 7.4,10 \mathrm{mM} \mathrm{NaCl}, 5 \mathrm{mM}$ $\mathrm{MgCl} 2,0.1 \% \mathrm{NP} 40$, and protease inhibitors. The extracted nuclei were lysed with $0.3 \mathrm{ml}$ of SDS lysis buffer (1\% SDS, $10 \mathrm{mM}$ EDTA, $50 \mathrm{mM}$ Tris- $\mathrm{HCl}, \mathrm{pH} 8.1$, and protease inhibitors). The lysates were sonicated by a Bioruptor UCD-200 (Diagenode, Liege, Belgium) to result in DNA fragments of $200-1000$ base pairs in length. Sonicated chromatin was divided into $100-\mu \mathrm{l}$ aliquots and suspended in $1 \mathrm{ml}$ of ChIP dilution buffer $(0.01 \%$ SDS, $1.1 \%$ Triton X-100, $1.2 \mathrm{mM}$ EDTA, $167 \mathrm{mM} \mathrm{NaCl}$, $16.7 \mathrm{mM}$ Tris-HCl, $\mathrm{pH} 8.1$, and protease inhibitors). A total of $2.5 \mu \mathrm{l}$ of bovine serum albumin $(100 \mathrm{mg} / \mathrm{ml})$ was added to each tube. One hundred microliters of the chromatin sample was removed as input DNA and stored at $+4^{\circ} \mathrm{C}$ until Proteinase $\mathrm{K}$ treatment and purification. One hundred microliters of antibody-bound (Nrf2, sc-722, and anti-rabbit IgG, sc-2027, Santa Cruz Biotechnology) Magna ChIP Magnetic Beads (Merck Millipore, Billerica, MA) was added to the chromatin samples, and the samples were incubated overnight at $+4^{\circ} \mathrm{C}$ on a rocking platform. On the next day, the beads were separated with a magnetic rack and washed five times with $\mathrm{LiCl}$ wash buffer [lsqb]100$\mathrm{mM}$ Tris, $\mathrm{pH}$ 7.5, $500 \mathrm{mM} \mathrm{LiCl,} \mathrm{1 \%} \mathrm{IGEPAL} \mathrm{(Sigma-Aldrich),} \mathrm{and} \mathrm{1 \%}$ sodium deoxycholate[rsqb] and twice with TE buffer $(10 \mathrm{mM}$ Tris-HCl, $\mathrm{pH} 7.5$, and $1 \mathrm{mM}$ EDTA). For elution, $200 \mu \mathrm{l}$ of elution buffer (1\% SDS and $0.1 \mathrm{M}$ NaHCO3) was added to the beads, and the mixture was incubated at RT for $1 \mathrm{~h}$ with vortexing of the beads every $15 \mathrm{~min}$. One hundred microliters of elution buffer was added to the input sample. Two microliters of Proteinase-K $(10 \mathrm{mg} / \mathrm{ml}$; Thermo Scientific, Waltham, MA) was added to all samples and the samples were incubated at $+65 \mathrm{C} \mathrm{O} / \mathrm{N}$. On the next day, DNA was purified with MinElute PCR Purification Kit (Qiagen, Hilden, Germany). Immunoprecipitated chromatin DNA was then used as a template for qPCR.

PCR of Chromatin Templates. qPCR of ChIP templates was performed using specific primers for the EDNRB chromatin region 4665 (5'-TAGATGTGCAGAAGCCAGGA-3' and 5'-CACCTCCCGTTATCAGTTCTC-3'), EDNRB chromatin region 5253 (5'-GGTGCGTTTGATGAACTGAA-3' and 5'-GAGAGCTGGTGGCTTCCATA-3'), or HMOX1 chromatin region (5' ${ }^{\prime}$-TGAGTAATCCTTTCCCGAGC-3' and 5' -GTGACTCAGCGAAAACAGACA-3') and FAST SYBR Green qPCR Master Mix in a total volume of $10 \mu \mathrm{l}$ in a LightCycler 480 System (Roche Applied Science, Mannheim, Germany).

ET-1 Enzyme-Linked Immunosorbent Assay. ET-1 concentration from cell culture medium was measured with Endothelin-1 Quantikine ELISA Kit (BD Biosciences, Minneapolis, MN) according to the manufacturer protocol.

Statistical Analysis. Each experiment was performed at least in triplicate and was repeated two to five times, and the representative experiment is presented. Statistical analysis was performed with GraphPad Prism (Version 5.03), and the data were analyzed by unpaired two-tailed $t$ test analysis ( $t$ test) for comparisons between two groups, and one-way analysis of variance (ANOVA) with Tukey's post hoc comparison for multiple comparisons. Data are expressed as the mean $\pm \mathrm{SD}$, and differences were considered significant as follows: $* P<0.05 ; * * P<0.01$; and $* * * P<0.001$. To calculate correlations, Pearson correlation test was applied.

\section{Results}

Previously, we studied Nrf2-dependent and -independent effects of OA- $\mathrm{NO}_{2}$ in human endothelial cells using a genomewide expression analysis. The data indicated that $\mathrm{OA}-\mathrm{NO}_{2}$ upregulated ET-B receptor mRNA expression in an Nrf2dependent manner (Kansanen et al., 2009). To verify this finding, HUVECs were treated with $\mathrm{OA}-\mathrm{NO}_{2}$, and the ET-B receptor mRNA expression was measured with quantitative PCR. HMOX1 and GCLM, genes that are well known to be induced in response to $\mathrm{OA}-\mathrm{NO}_{2}$ treatment (Kansanen et al., 2009), were used as a positive controls. OA- $\mathrm{NO}_{2}$ increased both HMOX1 (Fig. 1, A-C) and GCLM (Fig. 1, D-F) expression in a time- and concentration-dependent manner in HUVECs. When the expression of ET-B receptor was analyzed, the highest increase in expression after $\mathrm{OA}-\mathrm{NO}_{2}$ treatment was observed with $5 \mu \mathrm{M} \mathrm{OA}-\mathrm{NO}_{2}$. The ET-B receptor expression was increased 5.4-fold and 7.5-fold with $5 \mu \mathrm{M} \mathrm{OA-NO}{ }_{2}$ at 6 and $16 \mathrm{~h}$, respectively (Fig. 1, G-I).

The ET-B receptor is suggested to be the predominant receptor for ET-1 in endothelial cells. It mediates vasorelaxation and functions as a clearance receptor by removing ET-1 from the circulation. Vascular smooth muscle cells express both ET-A and ET-B receptors, and the activation of both receptors in these cells results in smooth muscle contraction (Schneider et al., 2007). We compared the OA-NO $\mathrm{N}_{2}$-induced ET-B expression both in HUVECs and in HASMCs and found
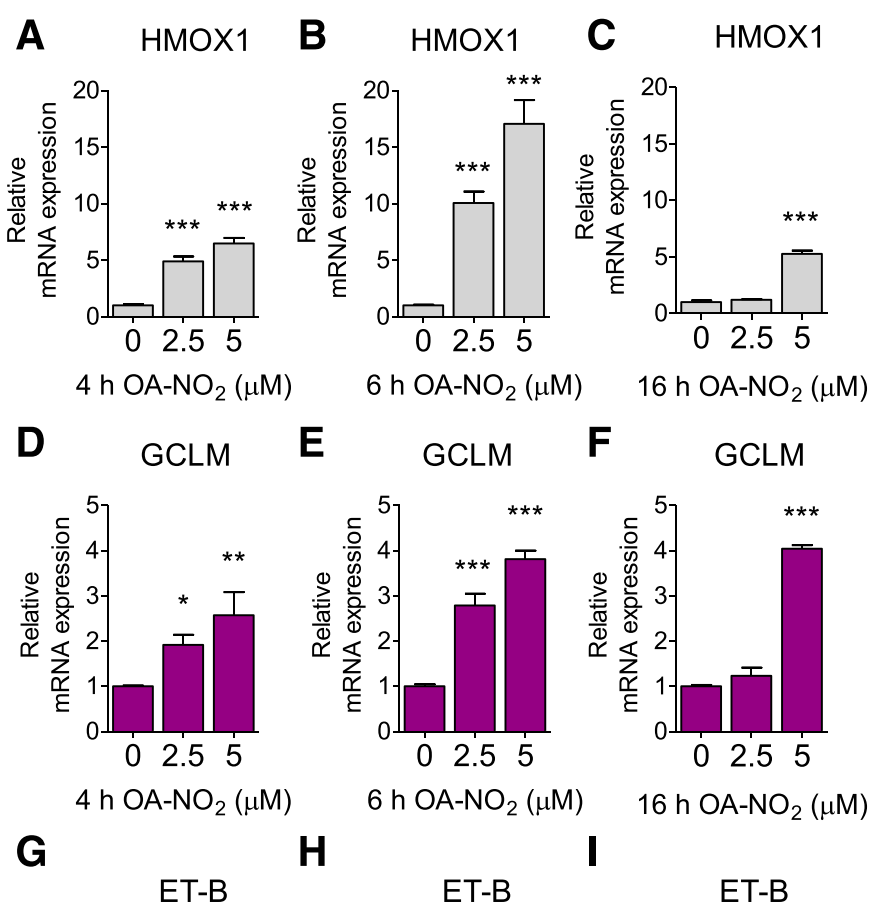

G

ET-B

\section{$\mathrm{H}$}
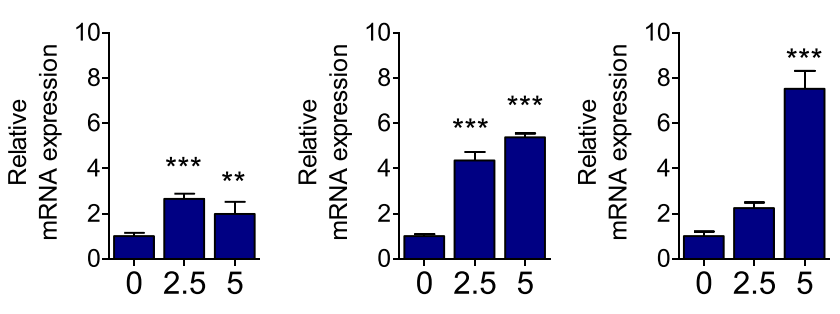

$4 \mathrm{~h} \mathrm{OA}-\mathrm{NO}_{2}(\mu \mathrm{M})$

Fig. 1. $\mathrm{OA}-\mathrm{NO}_{2}$ increases the expression of ET-B receptor in endothelial cells. HUVECs were treated with indicated times and concentrations of $\mathrm{OA}_{-} \mathrm{NO}_{2}$, after which the expressions of HMOX1 (A-C), GCLM (D-F), and ET-B (G-I) were measured with $\mathrm{qPCR}$. Values are presented as the mean \pm SD. $n=3$. ${ }^{*} P<0.05$, ${ }^{*} * P<0.01,{ }^{*} * P<0.001$ vs. control; ANOVA (A-I). 
that the increase in ET-B expression evoked by $\mathrm{OA}-\mathrm{NO}_{2}$ was substantially lower in HASMCs than in HUVECs (Fig. 2A). In HUVECs, $2.5 \mu \mathrm{M}$ OA-NO $\mathrm{N}_{2}$ induced ET-R receptor expression by 6.2 -fold, and $5 \mu \mathrm{M}$ OA- $\mathrm{NO}_{2}$ induced expression by 4.6-fold. In HASMCs, the fold induction after 2.5 and $5 \mu \mathrm{M}$ $\mathrm{OA}-\mathrm{NO}_{2}$ were 2.0 and 2.6 , respectively. The difference between the fold changes shown in Figs. 1 and 2 is likely because of donor-specific differences in HUVEC isolations. Furthermore, OA-NO $\mathrm{N}_{2}$ did not increase the expression of ET-A receptor in HASMCs, and HUVECs did not express any detectable ET-A mRNA (Fig. 2B). In comparison, $\mathrm{OA}-\mathrm{NO}_{2}$ induced the expression of Nrf2 target genes HMOX1 and glutamate-cysteine ligase regulatory subunit (GCLM) in both HUVECs and HASMCs. HMOX1 expression was higher in HASMCs (Fig. 2C), and there was no difference in GCLM mRNA expression when the two cell lines were compared (Fig. 2D). To study whether the higher ET-B receptor expression in HUVECs was due to the higher expression of Nrf2, both mRNA expression and nuclear Nrf2 translocation were measured. Nrf2 mRNA expression was higher in HASMCs, but the difference was significant only in basal condition (Fig. 2E). Because Nrf2 activation is mainly regulated at the post-transcriptional level (Suzuki and Yamamoto, 2015), nuclear translocation of $\mathrm{Nrf2}$ after $\mathrm{OA}-\mathrm{NO}_{2}$ treatment was measured. $\mathrm{OA}-\mathrm{NO}_{2}$ increased the nuclear accumulation of $\mathrm{Nrf} 2$ in both cell lines, and the accumulation was more pronounced in HAECs (Fig. 2, F and G). Thus, the lower ET-B induction in response to $\mathrm{OA}-\mathrm{NO}_{2}$ is not due to lower $\mathrm{Nrf2}$ expression, suggesting an alternative mechanism for more pronounced ET-B receptor expression in HUVECs.
To study whether Nrf2 mediates the OA-NO${ }_{2}$-induced upregulation of ET-B, the effect of Nrf2 overexpression was studied first. In HUVECs, AdNrf2 (Fig. 3A) resulted in a robust induction in ET-B mRNA (Fig. 3B). Next, the role of Nrf2 silencing on the OA-NO $\mathrm{N}_{2}$-induced ET-B expression was examined in different cultured endothelial cells. A siRNA approach was used to silence Nrf2 in both human venous and aortic endothelial cells. In HUVECs and HAECs, Nrf2-siRNA reduced Nrf2 expression $75 \%$ and $91 \%$ in basal conditions and by $70 \%$ and $93 \%$ in induced conditions, respectively (Fig. 3, $\mathrm{C}$ and D). Furthermore, ET-B expression was significantly reduced in HUVECs and HAECs in basal conditions (44\% and $77 \%$ ) and $\mathrm{OA}-\mathrm{NO}_{2}$ induced conditions (60\% and $83 \%$ ), respectively (Fig. 3, E and F). In addition, the role of Nrf2 in $\mathrm{OA}-\mathrm{NO}_{2}$-induced ET-B expression was studied in mouse endothelial cells isolated from wild-type and Nrf2 knockout (Nrf2-KO) mouse hearts. Similar to human endothelial cells, a significant reduction in ET-B expression was detected in both basal $(77 \%)$ and induced $(83 \%)$ conditions (Fig. 3G). These data show that in both human and mouse endothelial cells, Nrf2 is required for ET-B receptor mRNA expression.

Because ET-B receptor was expressed in an Nrf2-dependent manner in endothelial cells, we next studied whether ET-B is a direct target of Nrf2. Using in silico screening for Nrf2 binding sites (Kuosmanen et al., 2016), seven putative AREs were found in the vicinity of the ET-B gene $E D N R B$ (Fig. 4A). Two of the seven ARE sequences colocalized with ENCODE open chromatin markers (H3K4Me1 and H3K27Ac) and transcription factor (MafF, MafK, and BACH1) ChIP positions (Fig. 4A). Nrf2
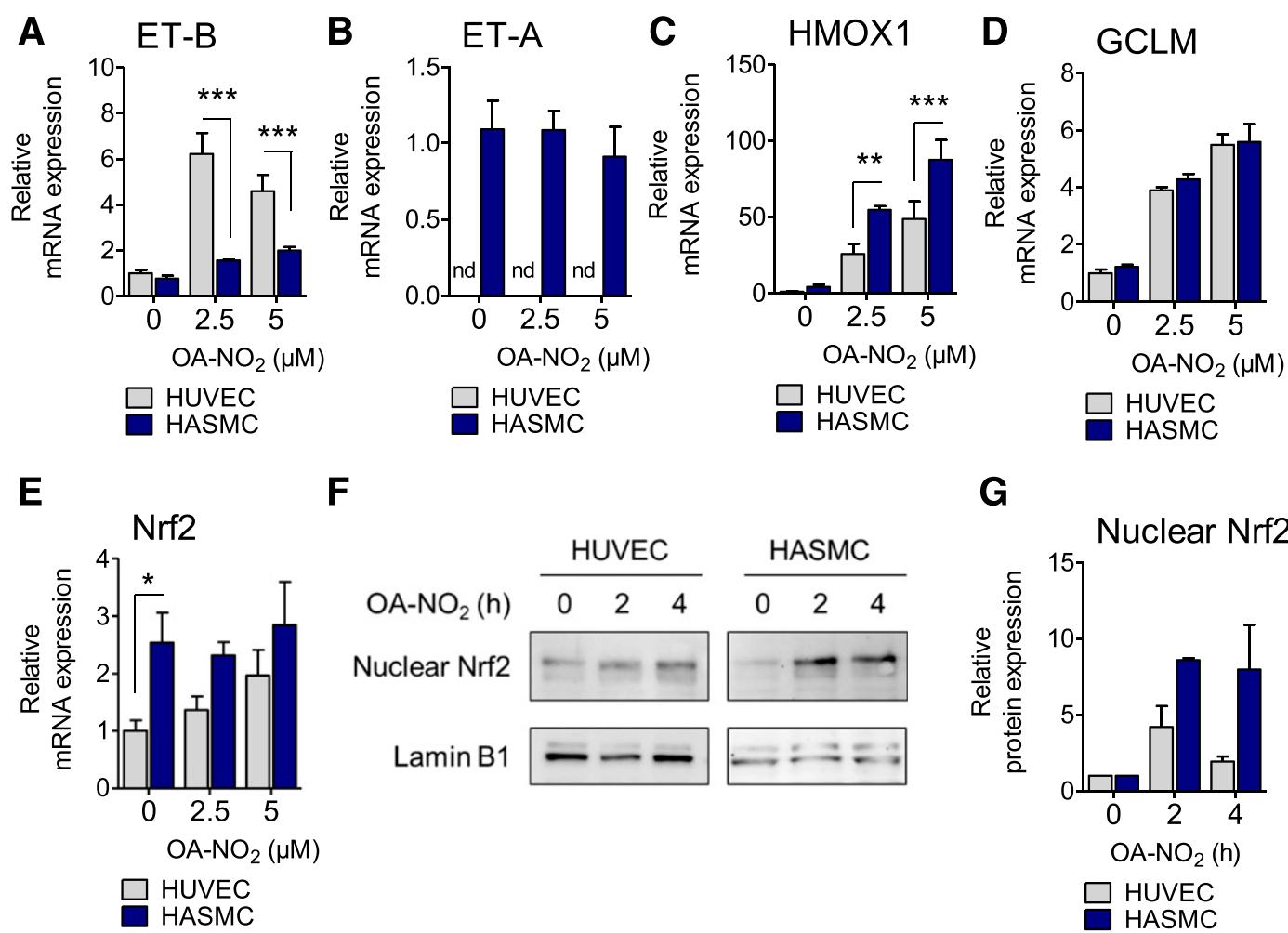

$\mathbf{F}$
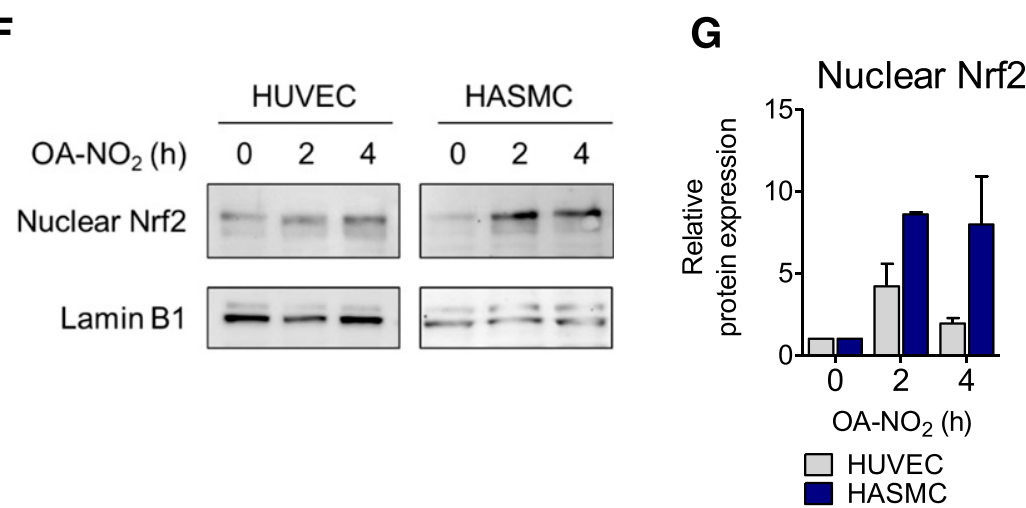

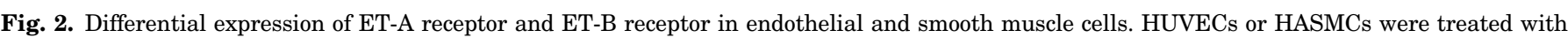

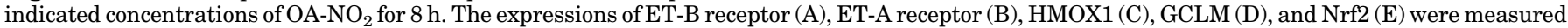

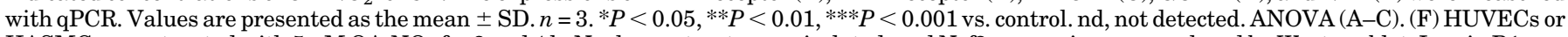

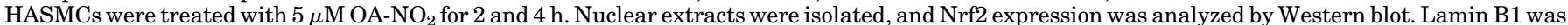

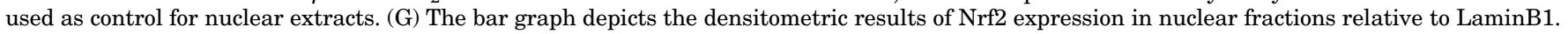




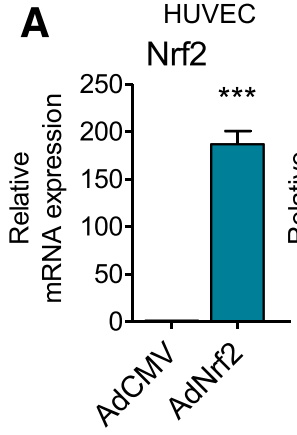

E

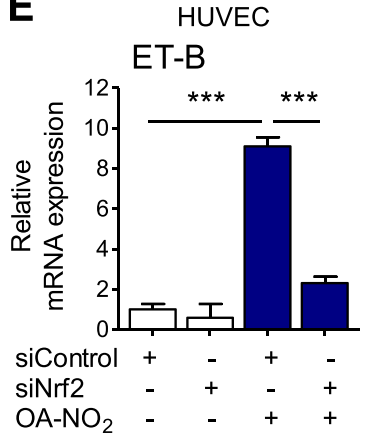

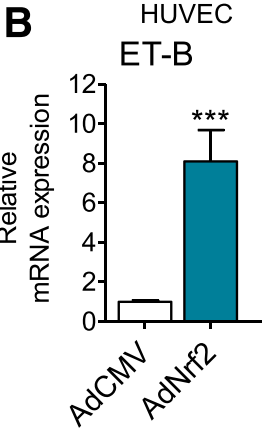

$\mathbf{F}$

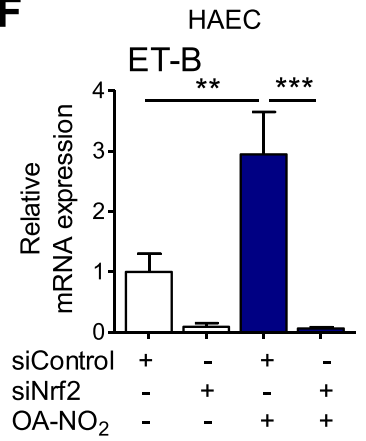

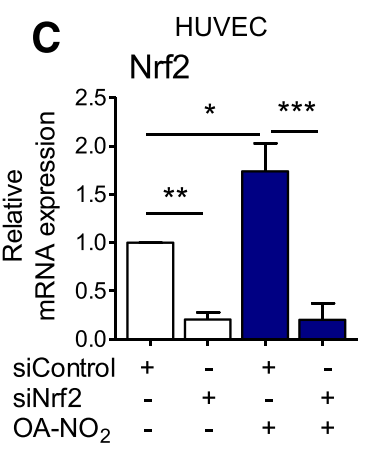

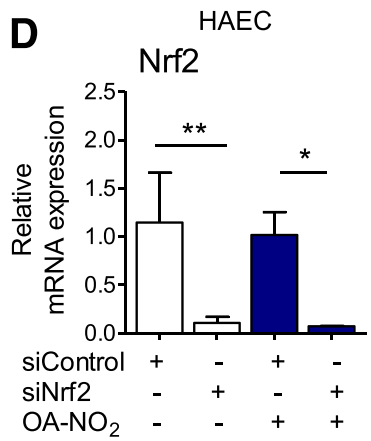

G

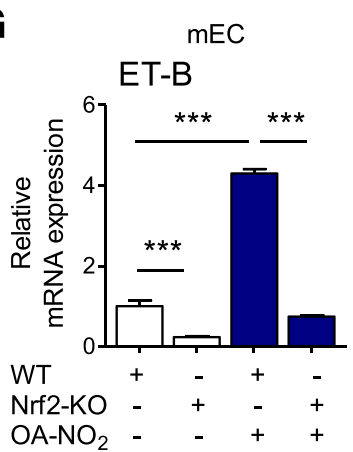

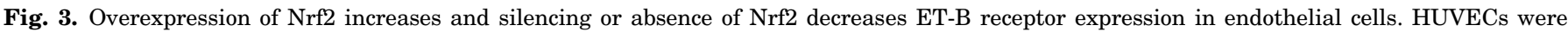

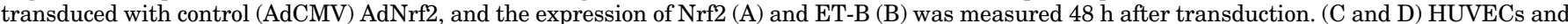

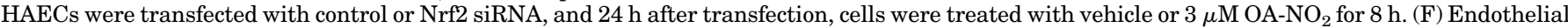

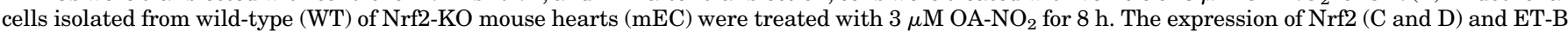

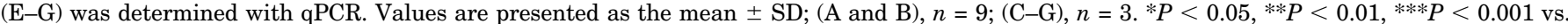
respective control. ANOVA, (C-G); $t$ test, (A and B).

heterodimerizes with small Maf proteins to bind ARE sequences, and BACH1 has been previously shown to bind AREs (Igarashi and Sun, 2006). These two AREs were located 4665 (Fig. 4B) and 5253 (Fig. 4C) base pairs from the gene transcription start site of the longest $E N D R B$ transcript. To study whether Nrf2 binds to these sites in endothelial cells, a ChIP analysis was performed. The analysis revealed increased binding of Nrf2 to the ARE site located 5253 base pairs upstream from the transcription start site 60 min after $\mathrm{OA}-\mathrm{NO}_{2}$ addition (Fig. 4E). However, even though $\mathrm{OA}-\mathrm{NO}_{2}$ increased the binding of Nrf2 to the ARE site located 4665 base pairs from the transcription start, the binding remained lower than the background. (Fig. 4D). The binding of Nrf2 to the distal enhancer region in the $H M O X 1$ gene was used as a positive control (Kansanen et al., 2011) (Fig. 4F).

The function of the ET-B receptor is to mediate the vasodilatory effects of ET-1, and it also functions as a decoy receptor to clear ET-1 from the circulation (Kelland et al., $2010 \mathrm{~b})$. To study the functional effect of $\mathrm{OA}-\mathrm{NO}_{2}-$ and Nrf2induced ET-B expression, ET-1 peptide concentration was measured from the cell culture medium. OA-NO $\mathrm{NO}_{2}$ was found to significantly decrease ET-1 concentration in the medium by $4 \mathrm{~h}$ after the addition of $\mathrm{OA}-\mathrm{NO}_{2}$ (Fig. 5A). After $24 \mathrm{~h}$, the ET-1 concentration was reduced by $41 \%$ (Fig. $5 \mathrm{~B}$ ). In addition, the overexpression of Nrf2 (Fig. 3A) decreased the amount of ET-1 detectable in the medium by $79 \%$ (Fig. 5C), and Nrf2 silencing (Fig. 3C) increased ET-1 concentration by 20\% (Fig. 5D). To investigate whether the change in extracellular ET-1 concentration was due to the transcriptional repression of the ET-1 gene $E D N 1$, the mRNA expression of $E D N 1$ was measured. In

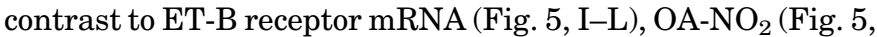
$\mathrm{E}$ and F), and Nrf2 overexpression (Fig. 5G) of Nrf2 silencing
(Fig. 5H) did not cause significant changes in EDN1 gene expression. These data indicate that the changes in ET-1 concentration after $\mathrm{OA}-\mathrm{NO}_{2}$ treatment or $\mathrm{Nrf} 2$ modulation are not explained by transcriptional changes in $E D N 1$ and, rather, correlate with the changes in ET-B receptor mRNA expression (Fig. 5, M-P).

Next, the role of ET-B receptor in $\mathrm{OA}-\mathrm{NO}_{2}-$ and Nrf2induced ET-1 clearance was investigated by using a specific ET-B antagonist, BQ788. Even though BQ-788 did not change the extracellular ET-1 concentration in basal conditions, treatment with $\mathrm{BQ}-788$ prior to the addition of $\mathrm{OA}-\mathrm{NO}_{2}$ abolished the reduction of ET-1 in the medium (Fig. 6A). Similar to $\mathrm{OA}-\mathrm{NO}_{2}$ treatment, ET-B receptor blockage with $\mathrm{BQ}-788$ reversed the reduction of ET-1 concentration after Nrf2 overexpression (Fig. 6B). Furthermore, Nrf2 silencing increased the amount of ET-1 in the cell culture medium (Fig. 5H; Fig. 6C). When ET-B receptor was blocked with BQ-788, the siNrf2-induced increase in ET-1 concentration was reduced from $2.2 \times$ to $1.7 \times$, further confirming that $\mathrm{OA}-\mathrm{NO}_{2}$ and Nrf2 modulate the ET-B-dependent clearance of ET-1 from the extracellular compartment.

Because ET-B receptor transcription is stringently regulated by Nrf2 (Fig. 3, C-E), the effect of Nrf2 silencing on OA-NO $\mathrm{N}_{2}$-induced ET-1 clearance was also examined. As expected, in nontreated conditions, Nrf2 silencing significantly increased and $\mathrm{OA}-\mathrm{NO}_{2}$ treatment decreased the amount of ET-1 by $61 \%$ in the cell culture medium (Fig. 6D). However, when Nrf2 was silenced, $\mathrm{OA}-\mathrm{NO}_{2}$ treatment decreased the ET-1 concentration even further (by 70\%). At the same time, in control the condition, siNrf2 increased the amount of ET-1 in the cell culture medium by $1.5 \times$, but in 

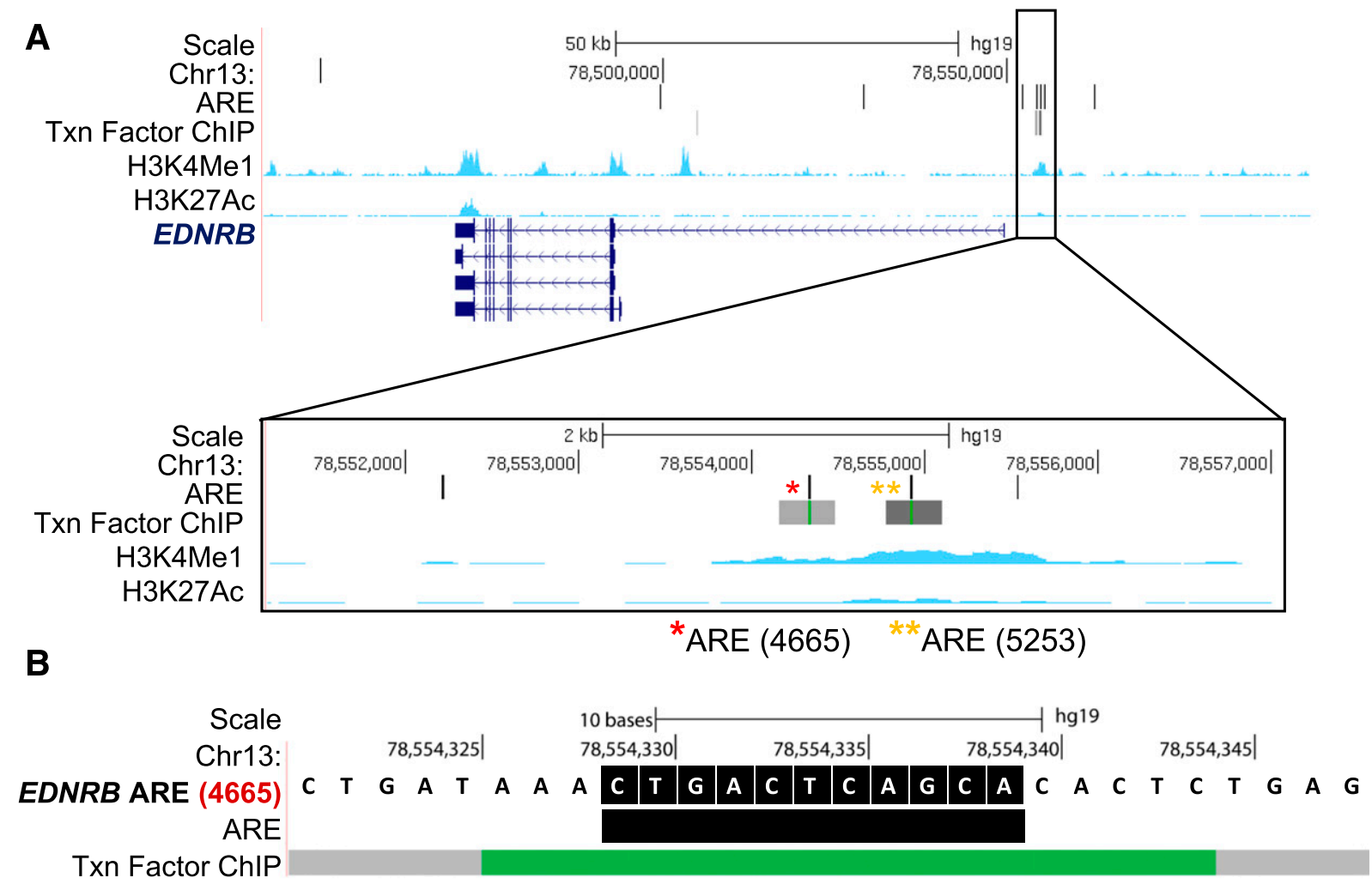

C

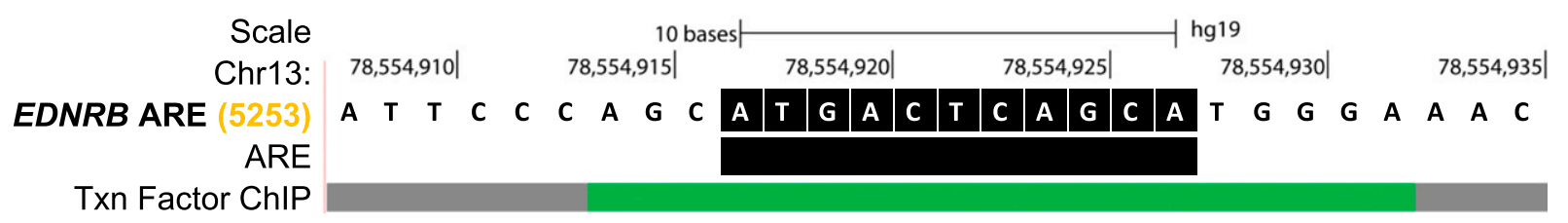

D

EDNRB ARE (4660)

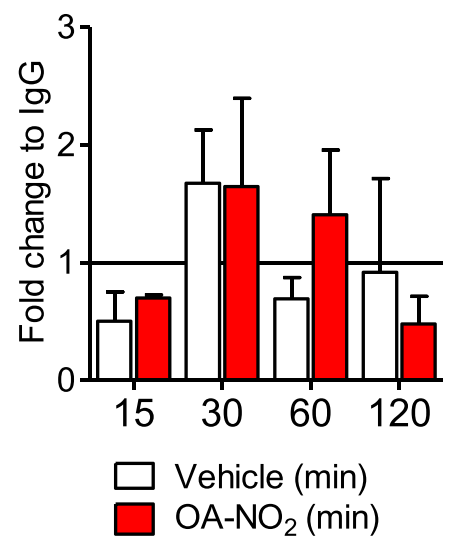

E

EDNRB ARE (5248)

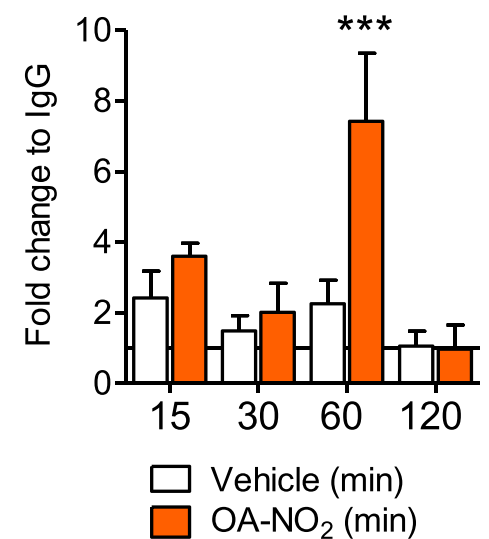

F

HMOX1 ARE

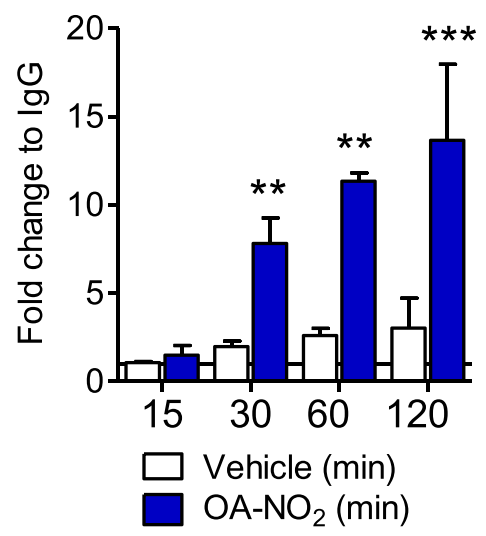

Fig. 4. OA- $\mathrm{NO}_{2}$ induces the binding of $\mathrm{Nrf2}$ to ARE sequence located on the active enhancer region at the ET-B gene $E D N R B$. (A) ARE prediction found seven ARE sequences from the enhancer region of EDNRD. Two of the AREs were colocalized with ENCODE Txn Factor ChIP positions. Detailed view showing AREs located 4665 base pairs (B) or 5253 base pairs (C) from the gene transcription start site of the longest ENDRB transcript. HUVECs were treated with indicated times with $5 \mu \mathrm{M}$ OA-NO $\mathrm{NO}_{2}$ and the binding of Nrf2 to AREs located in EDNRB (D-F) or HMOX1 (F) enhancer were analyzed with ChIP. Values are presented as the mean $\pm \operatorname{SEM}(n=3)$. $* P<0.05,{ }^{*} P<0.01, * * * P<0.001$ vs. control. Txn Factor ChIP-seq track displays combined MafF, MafK, and BACH1 binding signals in H1-hESC, HepG2, and IMR90 cell lines. H3K4Me1 and H3K27Ac tracks mark active chromatin regions in HUVECs. ANOVA (D and E). 
A

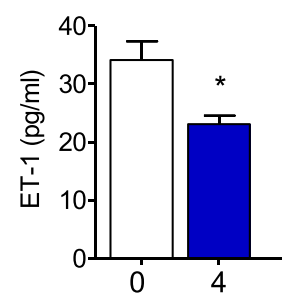

$\mathrm{OA}-\mathrm{NO}_{2}(\mathrm{~h})$

E

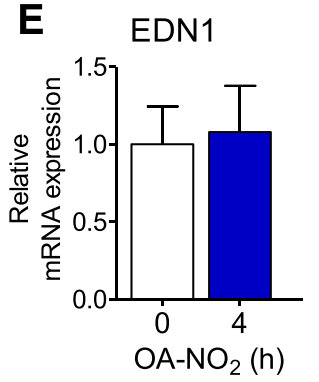

B

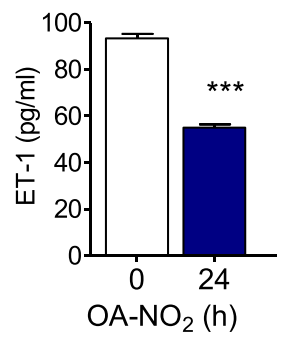

F

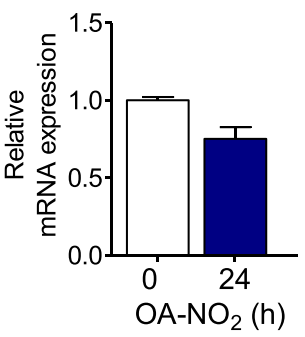

C

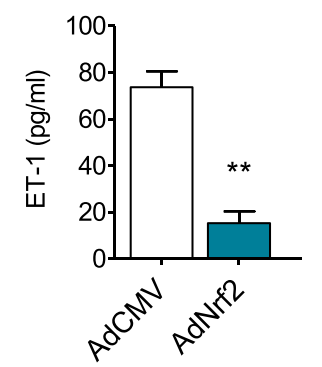

G

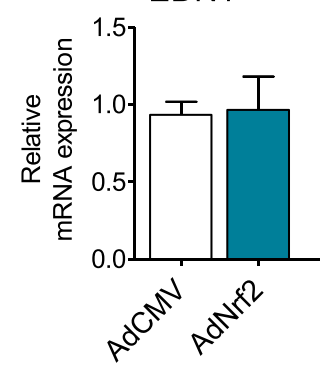

K

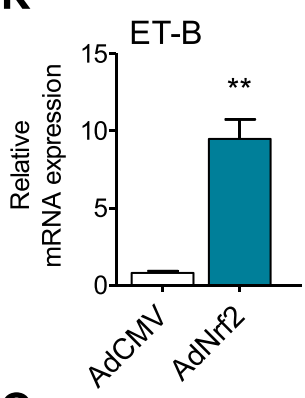

0

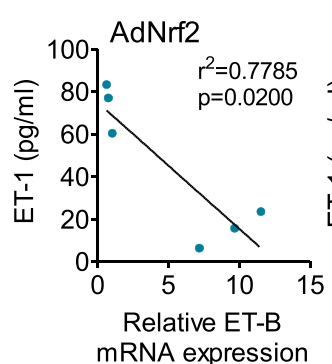

D

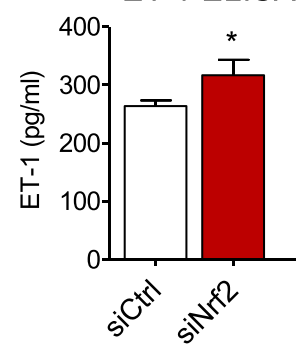

H EDN1

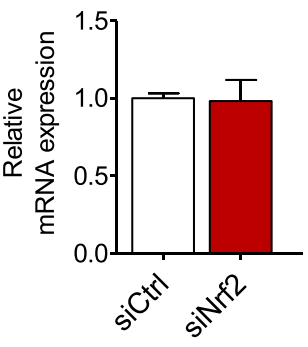

L ET-B

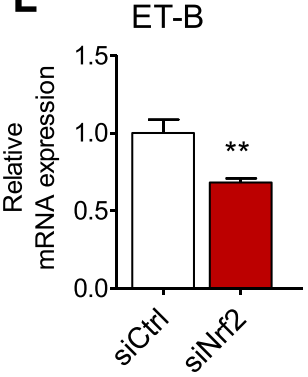

P

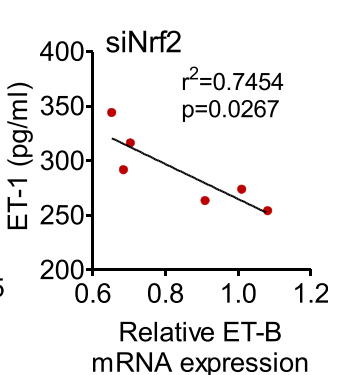

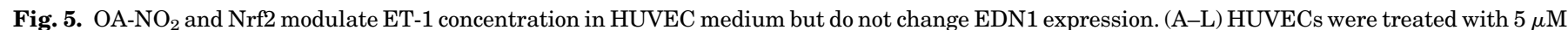

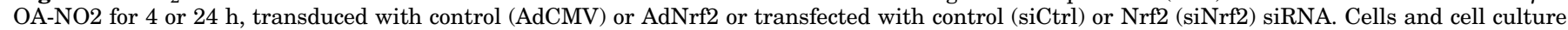

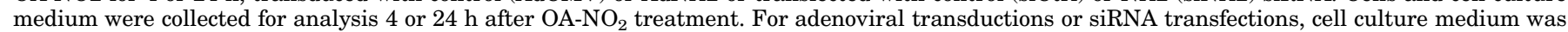

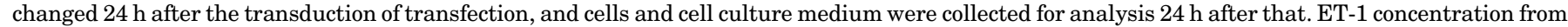

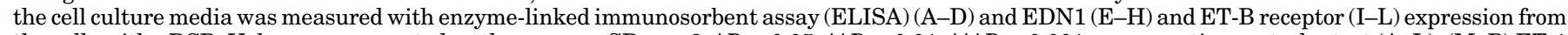

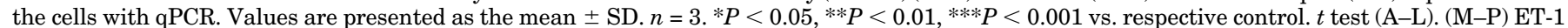

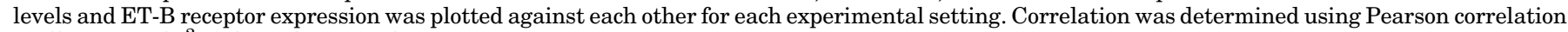
coefficient, and $r^{2}$ and $P$ values are shown.

OA- $\mathrm{NO}_{2}$-treated cells the increase was only $1.2 \times$ and did not reach statistical significance (Fig. 6D). In addition to extracellular ET-1 concentration, ET-B receptor mRNA expression was measured from the samples. The changes in ET-1 concentration in the cell culture medium correlated with the changes in ET-B receptor expression (Fig. 6, I and J). When the extracellular ET-1 concentration was blotted against the ET-B receptor expression, there was a high (Fig. $6, \mathrm{I}, \mathrm{K}$, and L) to moderate (Fig. 6J) correlation between the ET-1 concentrations and ET-B receptor expression. These data suggest that both $\mathrm{OA}-\mathrm{NO}_{2}$ and $\mathrm{Nrf} 2$ activation induce the clearance of ET-1 via ET-B receptor.

\section{Discussion}

In this study, we show for the first time that $\mathrm{OA}-\mathrm{NO}_{2}$ modulates the endothelin signaling by inducing Nrf2dependent expression of ET-B receptor, thereby decreasing extracellular ET-1 secreted by cultured endothelial cells. In addition, we show that Nrf2 directly regulates the ET-B 

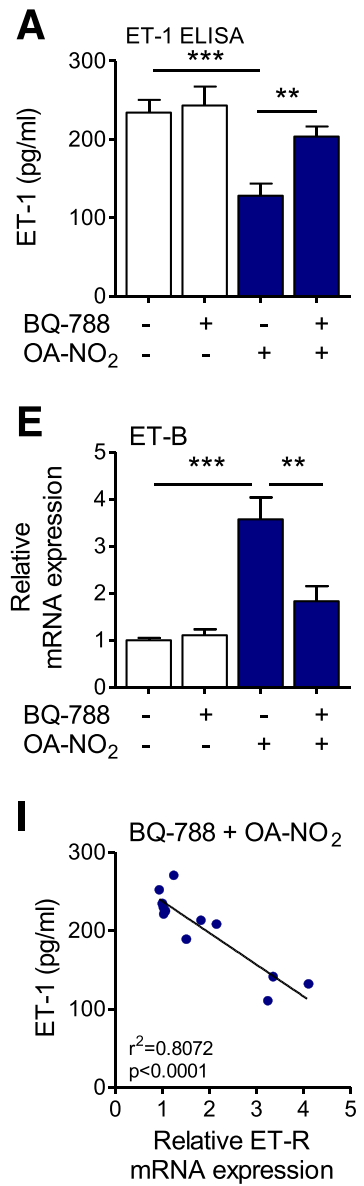

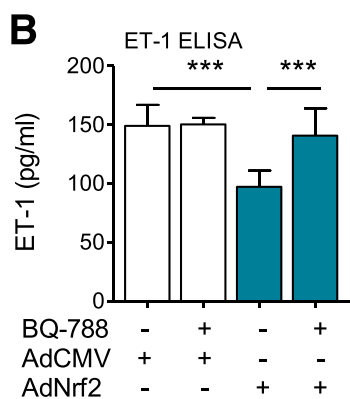

$\mathbf{F}$
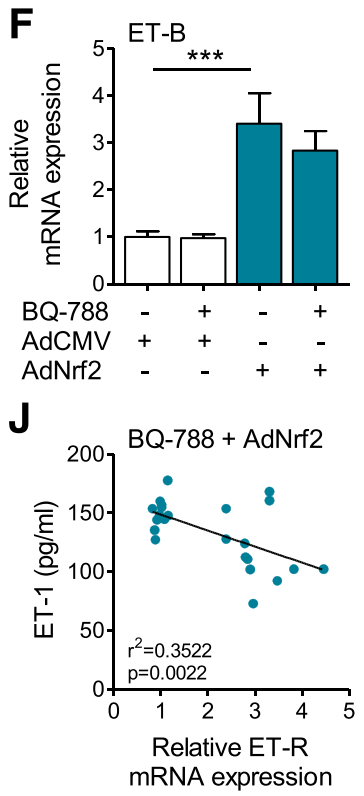
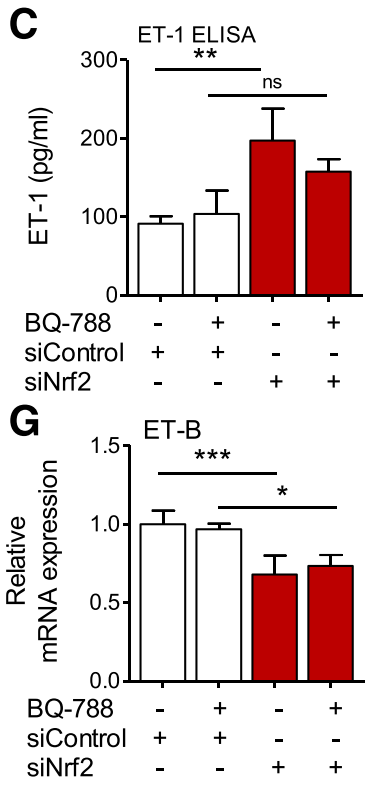

$\mathbf{K}$

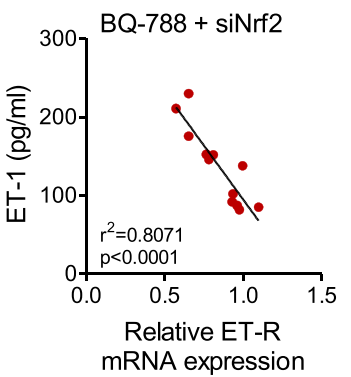

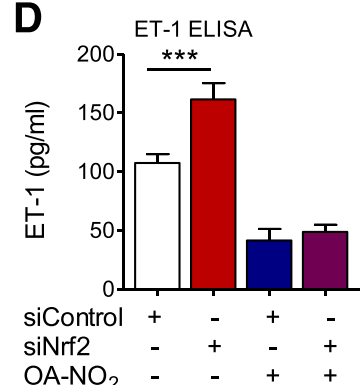

H

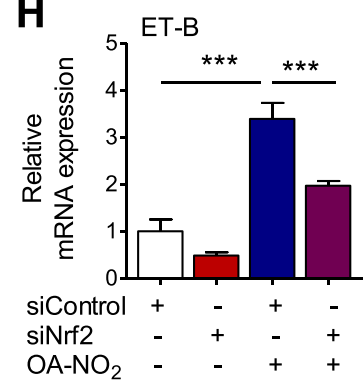

$\mathbf{L}$

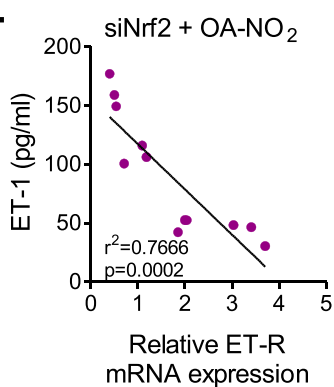

Fig. 6. OA-NO $\mathrm{N}_{2}$ - and Nrf2-induced ET-1 clearance is dependent on ET-B receptor. (A-E) HUVECs were treated with $1 \mu \mathrm{M}$ ET-B receptor antagonist BQ-788 for $8 \mathrm{~h}$, after which $5 \mu \mathrm{M} \mathrm{OA}-\mathrm{NO}_{2}$ was added for an additional $16 \mathrm{~h}$. (B and F) HUVECs were transduced with control (AdCMV) or AdNrf2. Twenty-four hours after transduction, cells were treated with $1 \mu \mathrm{M} \mathrm{BQ}-788$ for $24 \mathrm{~h}$. (C and G) HUVECs were transfected with control or Nrf2 siRNA, and $24 \mathrm{~h}$ after transfection cells were treated with $1 \mu \mathrm{M}$ BQ-788 for $24 \mathrm{~h}$. (D and H) HUVECs were transfected with control or Nrf2 siRNA, and $24 \mathrm{~h}$ after transfection cells were treated with $5 \mu \mathrm{M} \mathrm{OA}-\mathrm{NO}_{2}$ for $16 \mathrm{~h}$. ET- 1 concentration in cell culture medium was measured with enzyme-linked immunosorbent assay (ELISA) (A-D), and ET-B mRNA expression was measured with qPCR (E-H). Values are presented as the mean \pm SD. (A, C-E, G, and H), $n=3$; (B and $\mathrm{F}$ ), $n=6$ ). ${ }^{*} P<0.05,{ }^{*} P<<0.01,{ }^{*} * * P<0.001$. ANOVA (A-H). (I-L) ET-1 levels and ET-B receptor expression were plotted against each other for each experimental setting. Correlation was determined using the Pearson correlation coefficient, and $r^{2}$ and $P$ values are shown.

receptor gene $E D N R B$, and its expression is largely dependent on this transcription factor.

Nitro-fatty acids such as $\mathrm{OA}-\mathrm{NO}_{2}$ are endogenous reactive lipids formed when unsaturated fatty acids react with $\mathrm{NO}$ or NO-derived species (Schopfer et al., 2011). In vivo, nitro-fatty acids are measured at low nanomolar concentrations, but they are robustly elevated in inflammatory conditions (Rudolph et al., 2010b; Salvatore et al., 2013). The main mechanism and signaling action of $\mathrm{OA}-\mathrm{NO}_{2}$ is via post-transcriptional modification of regulatory proteins, such as peroxisome proliferator-activated receptor- $\gamma$ (Schopfer et al., 2010), Keap1 (Kansanen et al., 2011), and nuclear factor- $\kappa$ B (Cui et al., 2006). Furthermore, $\mathrm{OA}-\mathrm{NO}_{2}$ can increase NO bioavailability via endothelial NO synthase phosphorylation (Khoo et al., 2010). OA-NO $\mathrm{N}_{2}$ has been shown to be beneficial in murine models of vascular disease (Cole et al., 2009; Rudolph et al., 2010a), type 2 diabetes (Schopfer et al., 2010), and both myocardial (Rudolph et al., 2010b) and renal (Wang et al., 2010) ischemia-reperfusion injury. Furthermore, in an angiotensin II-induced hypertension in mice, $\mathrm{OA}-\mathrm{NO}_{2}$ is shown to reduce blood pressure by direct adduction of the $\mathrm{AT}_{1}$ receptor (Zhang et al., 2010). In addition, $\mathrm{OA}-\mathrm{NO}_{2}$ can inhibit the enzymatic activity of epoxyeicosatrienoic acid hydrolyzing soluble epoxide hydrolase by adduction to Cys521 in the vicinity of its catalytic center, and this inhibition may mediate the antihypertensive effects of OA-NO ${ }_{2}$ (Charles et al., 2014). In this study, we show an additional potential mechanism by which $\mathrm{OA}-\mathrm{NO}_{2}$ may reduce blood pressure. This mechanism involves a Nrf2-dependent increase in ET-B receptor expression, which leads to increased clearance of ET-1. In previous studies, we have shown that $\mathrm{OA}-\mathrm{NO}_{2}$ induces Nrf2-dependent activation via modification of Cys residues in Nrf2 inhibitor protein Keap1 (Kansanen et al., 2011). Therefore, it can be postulated that the increase in Nrf2-dependent ET-B receptor expression is also mediated via post-translational modification of Keap1.

ET-1 is a vasoactive 21-amino acid cyclic peptide, which was originally isolated from porcine aortic endothelial cells (Yanagisawa et al., 1988). Several cell types can synthesize and release ET-1, but the most important biologic source is the endothelium. ET-1 has a half-life of less than 2 min in blood (Dhaun et al., 2008), and it is rapidly taken up by the vasculature. The uptake involves the binding of ET-1 to cell surface ET-B receptors and the internalization of the ligand bound receptor, followed by receptor degradation, probably 
within lysosomes (Bremnes et al., 2000). Endothelin receptors in different tissues regulate diverse physiologic responses including vasoconstriction, vasodilation, clearance of ET-1, and renal sodium absorption (Schneider et al., 2007; Kohan et al., 2011). ET-1 has been shown to play a role in high saltinduced hypertension, likely via the combined effect of impaired ET-B receptor-mediated ET-1 clearance as well as the activation of the ET-A receptor (Gariepy et al., 2000; Pollock and Pollock, 2001; Amiri et al., 2010). Therefore, the effects of selective ET-A, ET-B, or dual ET-A/ET-B receptor antagonists on hypertension have been investigated. Results show that although ET-A or both ET-A and ET-B receptor inhibition with selective ET-A or dual ET-A/ET-B antagonists reduce blood pressure (Krum et al., 1998; Nakov et al., 2002), more profound effects are achieved with ET-B blockers, which increase blood pressure (Strachan et al., 1999; Opgenorth et al., 2000). These results suggest that the more important physiologic role of ET-1 in systemic hypertension is through ET-B receptor actions that promote vasodilatation via preventing ET-A-mediated constriction. A major drawback for ET receptor antagonists has been the high incidence of side effects, including fluid retention, edema, and hepatotoxicity, which largely prohibits their use in the general population to treat hypertension (Hoeper, 2009; Laffin and Bakris, 2015). Therefore, new treatment options are needed. In this study, both $\mathrm{OA}-\mathrm{NO}_{2}$ and $\mathrm{Nrf} 2$ overexpression induced the expression of the ET-B receptor expression in endothelial cells and decreased the amount of ET-1 in cell culture medium. In addition, the silencing of Nrf2 decreased ET-B receptor expression and increased the ET-1 concentration in cell culture medium. Our data suggest that Nrf2 and Nrf2-inducing agents, via promoting the clearance of ET-1 by ET-B receptor, may reduce circulating ET-1 levels thereby limiting its vasoconstrictive effects. In our study, the ET-B receptor antagonist BQ-788 did not change the extracellular concentration of ET-1 in basal conditions but reversed the reduction in ET-1 concentration after $\mathrm{OA}-\mathrm{NO}_{2}$ treatment or Nrf2 modulation. Because BQ-788 cannot displace the bound ET-1 from the ET-B receptor (Johnström et al., 2005), we suggest that the change in ET-B receptor expression was needed for the change in the extracellular concentration of ET-1. Our results are consistent with the findings that $\mathrm{OA}-\mathrm{NO}_{2}$ has antihypertensive effects in mouse models of hypertension (Zhang et al., 2010; Charles et al., 2014). Furthermore, increasing or restoring ET-B receptor function may also be helpful in other diseases where ET-1 production is increased, such as chronic kidney disease (Cottone et al., 2009) and pulmonary arterial hypertension (PAH) (McLaughlin and McGoon, 2006).

The current clinical use of ET receptor antagonists is limited to $\mathrm{PAH}$. PAH is a progressive disease characterized by the elevation of pulmonary artery pressure and adverse vascular remodeling, leading to right ventricular dysfunction. $\mathrm{PAH}$ has a poor prognosis and limited treatment options (McLaughlin and McGoon, 2006). Endothelial ET-B receptor function is important in limiting the development of $\mathrm{PAH}$ in response to hypoxia (Kelland et al., 2010a). ET-1 levels are elevated in patients with $\mathrm{PAH}$, and the clearance of ET-1 in the pulmonary vasculature is reduced. Plasma levels of ET-1 correlate with the severity of PAH (McLaughlin and McGoon, 2006). Previously, the effect of $\mathrm{OA}-\mathrm{NO}_{2}$ on $\mathrm{PAH}$ has been studied using the hypoxia-induced mouse model (Klinke et al., 2014).
$\mathrm{OA}-\mathrm{NO}_{2}$ reversed the development of $\mathrm{PAH}$ and consequent right ventricular dysfunction. The protective effect of $\mathrm{OA}-\mathrm{NO}_{2}$ was linked to a decrease in oxidative inflammatory responses in pulmonary smooth muscle cells and macrophages. $\mathrm{OA}-\mathrm{NO}_{2}$ inhibited pulmonary smooth muscle cell proliferation and reduced right ventricular remodeling (Klinke et al., 2014). Furthermore, in an obesity-induced model of PAH, treatment with $\mathrm{OA}-\mathrm{NO}_{2}$ improved right ventricular function (Kelley et al., 2014). Our data suggest that in addition to the effects on pulmonary smooth muscle cells (Klinke et al., 2014), the beneficial effect of $\mathrm{OA}-\mathrm{NO}_{2}$ in $\mathrm{PAH}$ may be related to the regulation of the endothelin system, because $\mathrm{OA}-\mathrm{NO}_{2}$ increases the clearance of ET-1 via ET-B receptor upregulation. Interestingly, another study by Eba et al. (2013) showed that mice deficient in the Nrf2-inhibiting protein Keap1 that have a sustained increase in Nrf2 activity are protected against hypoxia-induced pulmonary alterations related to $\mathrm{PAH}$, whereas these were aggravated in Nrf2-deficient mice. Similar to genetic overexpression, the Nrf2 inducer oltipraz afforded protection against pulmonary artery muscularization in wild-type mice but not in Nrf2-deficient mice (Eba et al., 2013), highlighting the therapeutic potential of Nrf2 activators in the treatment of PAH.

Our results suggest that there is a cell type-specific difference in the regulation of the ET-B receptor mRNA in HUVECs and HASMCs. In contrast to the Nrf2 target gene and Nrf2 mRNA expression, $\mathrm{OA}-\mathrm{NO}_{2}$ had a substantially smaller effect on ET-B receptor mRNA expression in HASMCs than in HUVECs. As cell type-specific gene regulation is largely regulated by epigenetic mechanisms, the different response in these cells lines may be due to the difference in methylation of gene regulatory regions. Methylation of these regions renders chromatin inaccessible to binding of a given transcription factor in one cell type, whereas the chromatin is maintained in an open conformation allowing transcription factor binding in another cell type (Shirodkar et al., 2013). The ET-B receptors in endothelial cells function to maintain an appropriate plasma level of ET-1, and the function of ET-B receptors in other cell types such as smooth muscle cells is less clear, which may explain the cell type-specific difference in the ET-B receptor expression.

To conclude, we have shown that Nrf2 regulates $\mathrm{OA}-\mathrm{NO}_{2}-$ induced transcription of ET-B in vascular endothelial cells. The effect of $\mathrm{OA}-\mathrm{NO}_{2}$ did not change the expression of the ET-A receptor and had a substantially smaller effect on ET-B receptor expression in smooth muscle cells. Furthermore, we show that both $\mathrm{OA}-\mathrm{NO}_{2}$ and $\mathrm{Nrf} 2$ regulate the ET-Bdependent clearance of ET-1 in endothelial cells. Therefore, we suggest that $\mathrm{OA}-\mathrm{NO}_{2}$ may alleviate the vasoconstrictive effects of ET-1 by removing it from the circulation, thus potentially affecting blood pressure regulation.

\section{Acknowledgments}

The authors thank Dr. Bruce A. Freeman (University of Pittsburgh, Pittsburgh, PA) for the generous gift of nitro-oleic acid; Dr. Masayuki Yamamoto (Tohoku University, Sendai, Japan) for providing the Nrf2deficient mice; and Arja Korhonen for technical assistance.

\footnotetext{
Authorship Contributions

Participated in research design: Kansanen and Levonen.

Conducted experiments: Kansanen, Kuosmanen, Ruotsalainen, and Hynynen.

Performed data analysis: Kansanen.
} 
Wrote or contributed to the writing of the manuscript: Kansanen, Kuosmanen, Ruotsalainen, and Levonen.

\section{References}

Amiri F, Ko EA, Javeshghani D, Reudelhuber TL, and Schiffrin EL (2010) Deleterious combined effects of salt-loading and endothelial cell restricted endothelin-1 overexpression on blood pressure and vascular function in mice. J Hypertens $\mathbf{2 8}$ 1243-1251.

Baker LM, Baker PR, Golin-Bisello F, Schopfer FJ, Fink M, Woodcock SR, Branchaud BP, Radi R, and Freeman BA (2007) Nitro-fatty acid reaction with glutathione and cysteine. Kinetic analysis of thiol alkylation by a Michael addition reaction. $J$ Biol Chem 282:31085-31093.

Batthyany C, Schopfer FJ, Baker PR, Durán R, Baker LM, Huang Y, Cerveñansky C, Branchaud BP, and Freeman BA (2006) Reversible post-translational modification of proteins by nitrated fatty acids in vivo. J Biol Chem 281:20450-20463.

Bremnes T, Paasche JD, Mehlum A, Sandberg C, Bremnes B, and Attramadal H (2000) Regulation and intracellular trafficking pathways of the endothelin receptors. J Biol Chem 275:17596-17604.

Charles RL, Rudyk O, Prysyazhna O, Kamynina A, Yang J, Morisseau C, Hammock BD, Freeman BA, and Eaton P (2014) Protection from hypertension in mice by the Mediterranean diet is mediated by nitro fatty acid inhibition of soluble epoxide hydrolase. Proc Natl Acad Sci U S A 111:8167-8172.

Cole MP, Rudolph TK, Khoo NKH, Motanya UN, Golin-Bisello F, Wertz JW, Schopfer FJ, Rudolph V, Woodcock SR, Bolisetty S, et al. (2009) Nitro-fatty acid inhibition of neointima formation after endoluminal vessel injury. Circ Res 105:965-972.

Cottone S, Mulè G, Guarneri M, Palermo A, Lorito MC, Riccobene R, Arsena R, Vaccaro F, Vadalà A, Nardi E, et al. (2009) Endothelin-1 and F2-isoprostane relate to and predict renal dysfunction in hypertensive patients. Nephrol Dial Transplant 24:497-503.

Cui T, Schopfer FJ, Zhang J, Chen K, Ichikawa T, Baker PRS, Batthyany C, Chacko BK, Feng X, Patel RP, et al. (2006) Nitrated fatty acids: endogenous antiinflammatory signaling mediators. J Biol Chem 281:35686-35698.

Dhaun N, Goddard J, Kohan DE, Pollock DM, Schiffrin EL, and Webb DJ (2008) Role of endothelin-1 in clinical hypertension: 20 years on. Hypertension 52:452-459.

Eba S, Hoshikawa Y, Moriguchi T, Mitsuishi Y, Satoh H, Ishida K, Watanabe T, Shimizu T, Shimokawa H, Okada Y, et al. (2013) The nuclear factor erythroid 2-related factor 2 activator oltipraz attenuates chronic hypoxia-induced cardiopulmonary alterations in mice. Am J Respir Cell Mol Biol 49:324-333.

Gariepy CE, Ohuchi T, Williams SC, Richardson JA, and Yanagisawa M (2000) Saltsensitive hypertension in endothelin-B receptor-deficient rats. J Clin Invest 105:925-933.

Hoeper MM (2009) Liver toxicity: the Achilles' heel of endothelin receptor antagonist therapy? Eur Respir $J$ 34:529-530.

Igarashi K and Sun J (2006) The heme-Bach1 pathway in the regulation of oxidative stress response and erythroid differentiation. Antioxid Redox Signal 8:107-118.

Johnström P, Fryer TD, Richards HK, Harris NG, Barret O, Clark JC, Pickard JD and Davenport AP (2005) Positron emission tomography using 18F-labelled endothelin-1 reveals prevention of binding to cardiac receptors owing to tissuespecific clearance by ETB receptors in vivo. Br J Pharmacol 144:115-122.

Kansanen E, Bonacci G, Schopfer FJ, Kuosmanen SM, Tong KI, Leinonen H, Woodcock SR, Yamamoto M, Carlberg C, Ylä-Herttuala S, et al. (2011) Electrophilic nitro-fatty acids activate NRF2 by a KEAP1 cysteine 151-independent mechanism. $J$ Biol Chem 286:14019-14027.

Kansanen E, Jyrkkänen H-K, Volger OL, Leinonen H, Kivelä AM, Häkkinen S-K Woodcock SR, Schopfer FJ, Horrevoets AJ, Ylä-Herttuala S, et al. (2009) Nrf2 dependent and -independent responses to nitro-fatty acids in human endothelial cells: identification of heat shock response as the major pathway activated by nitrooleic acid. J Biol Chem 284:33233-33241.

Kansanen E, Jyrkkänen HK, and Levonen AL (2012) Activation of stress signaling pathways by electrophilic oxidized and nitrated lipids. Free Radic Biol Med $\mathbf{5 2}$ 973-982.

Kelland NF, Bagnall AJ, Morecroft I, Gulliver-Sloan FH, Dempsie Y, Nilsen M, Yanagisawa M, Maclean MR, Kotelevtsev YV, and Webb DJ (2010a) Endothelial ET(B) limits vascular remodelling and development of pulmonary hypertension during hypoxia. $J$ Vasc Res 47:16-22

Kelland NF, Kuc RE, McLean DL, Azfer A, Bagnall AJ, Gray GA, Gulliver-Sloan FH, Maguire JJ, Davenport AP, Kotelevtsev YV, et al. (2010b) Endothelial cell-specific ETB receptor knockout: autoradiographic and histological characterisation and crucial role in the clearance of endothelin-1. Can J Physiol Pharmacol 88:644-651.

Kelley EE, Baust J, Bonacci G, Golin-Bisello F, Devlin JE, St Croix CM, Watkins SC, Gor S, Cantu-Medellin N, Weidert ER, et al. (2014) Fatty acid nitroalkenes ameliorate glucose intolerance and pulmonary hypertension in high-fat diet-induced obesity. Cardiovasc Res 101:352-363.

Khoo NKH, Rudolph V, Cole MP, Golin-Bisello F, Schopfer FJ, Woodcock SR, Batthyany C, and Freeman BA (2010) Activation of vascular endothelial nitric oxide synthase and heme oxygenase-1 expression by electrophilic nitro-fatty acids. Free Radic Biol Med 48:230-239.

Kivelä AM, Mäkinen PI, Jyrkkänen H-K, Mella-Aho E, Xia Y, Kansanen E, Leinonen H, Verma IM, Ylä-Herttuala S, and Levonen A-L (2010) Sulforaphane inhibits endothelial lipase expression through NF-кB in endothelial cells. Atherosclerosis 213:122-128

Klinke A, Möller A, Pekarova M, Ravekes T, Friedrichs K, Berlin M, Scheu KM, Kubala L, Kolarova H, Ambrozova G, et al. (2014) Protective effects of 10-nitrooleic acid in a hypoxia-induced murine model of pulmonary hypertension. Am $J$ Respir Cell Mol Biol 51:155-162.

Kohan DE, Rossi NF, Inscho EW, and Pollock DM (2011) Regulation of blood pressure and salt homeostasis by endothelin. Physiol Rev 91:1-77.

Krum H, Viskoper RJ, Lacourciere Y, Budde M, and Charlon V; Bosentan Hypertension Investigators (1998) The effect of an endothelin-receptor antagonist, bosentan, on blood pressure in patients with essential hypertension. $N$ Engl J Med 338:784-790.

Kuosmanen SM, Viitala S, Laitinen T, Peräkylä M, Pölönen P, Kansanen E, Leinonen H, Raju S, Wienecke-Baldacchino A, Närvänen A, et al. (2016) The effects of sequence variation on genome-wide NRF2 binding-new target genes and regulatory SNPs. Nucleic Acids Res 44:1760-1775.

Kwak M-K, Wakabayashi N, Itoh K, Motohashi H, Yamamoto M, and Kensler TW (2003) Modulation of gene expression by cancer chemopreventive dithiolethiones through the Keap1-Nrf2 pathway. Identification of novel gene clusters for cell survival. J Biol Chem 278:8135-8145.

Laffin LJ and Bakris GL (2015) Endothelin antagonism and hypertension: an evolving target. Semin Nephrol 35:168-175.

Lee T-S, Tsai H-L, and Chau L-Y (2003) Induction of heme oxygenase-1 expression in murine macrophages is essential for the anti-inflammatory effect of low dose 15-deoxy-delta 12,14-prostaglandin J2. J Biol Chem 278:19325-19330.

Levonen AL, Inkala M, Heikura T, Jauhiainen S, Jyrkkänen HK, Kansanen E, Määttä K, Romppanen E, Turunen P, Rutanen J, et al. (2007) Nrf2 gene transfer induces antioxidant enzymes and suppresses smooth muscle cell growth in vitro and reduces oxidative stress in rabbit aorta in vivo. Arterioscler Thromb Vasc Biol 27:741-747.

Levonen A-L, Landar A, Ramachandran A, Ceaser EK, Dickinson DA, Zanoni G, Morrow JD, and Darley-Usmar VM (2004) Cellular mechanisms of redox cell signalling: role of cysteine modification in controlling antioxidant defences in response to electrophilic lipid oxidation products. Biochem J 378:373-382.

McLaughlin VV and McGoon MD (2006) Pulmonary arterial hypertension. Circula tion 114:1417-1431.

Nadtochiy SM, Baker PRS, Freeman BA, and Brookes PS (2009) Mitochondrial nitroalkene formation and mild uncoupling in ischaemic preconditioning: implications for cardioprotection. Cardiovasc Res 82:333-340.

Nakov R, Pfarr E, and Eberle S; HEAT Investigators (2002) Darusentan: an effective endothelinA receptor antagonist for treatment of hypertension. Am J Hypertens 15: 583-589.

Opgenorth TJ, Wessale JL, Dixon DB, Adler AL, Calzadilla SV, Padley RJ, and WuWong JR (2000) Effects of endothelin receptor antagonists on the plasma immunoreactive endothelin-1 level. J Cardiovasc Pharmacol 36(5 Suppl. 1):S292-S296.

Pollock DM and Pollock JS (2001) Evidence for endothelin involvement in the response to high salt. Am J Physiol Renal Physiol 281:F144-F150.

Rudolph TK, Rudolph V, Edreira MM, Cole MP, Bonacci G, Schopfer FJ, Woodcock SR, Franek A, Pekarova M, Khoo NK, et al. (2010a) Nitro-fatty acids reduce atherosclerosis in apolipoprotein E-deficient mice. Arterioscler Thromb Vasc Biol 30: 938-945.

Rudolph V, Rudolph TK, Schopfer FJ, Bonacci G, Woodcock SR, Cole MP, Baker PR, Ramani R, and Freeman BA (2010b) Endogenous generation and protective effects of nitro-fatty acids in a murine model of focal cardiac ischaemia and reperfusion. Cardiovasc Res 85:155-166.

Salvatore SR, Vitturi DA, Baker PR, Bonacci G, Koenitzer JR, Woodcock SR, Freeman BA, and Schopfer FJ (2013) Characterization and quantification of endogenous fatty acid nitroalkene metabolites in human urine. J Lipid Res 54:1998-2009.

Schneider MP, Boesen EI, and Pollock DM (2007) Contrasting actions of endothelin ET(A) and ET(B) receptors in cardiovascular disease. Annu Rev Pharmacol Toxicol 47:731-759.

Schopfer FJ, Cole MP, Groeger AL, Chen CS, Khoo NKH, Woodcock SR, Golin-Bisello F, Motanya UN, Li Y, Zhang J, et al. (2010) Covalent peroxisome proliferatoractivated receptor $\gamma$ adduction by nitro-fatty acids: selective ligand activity and anti-diabetic signaling actions. J Biol Chem 285:12321-12333.

Schopfer FJ, Cipollina C, and Freeman BA (2011) Formation and signaling actions of electrophilic lipids. Chem Rev 111:5997-6021.

Shirodkar AV, St Bernard R, Gavryushova A, Kop A, Knight BJ, Yan MSC, Man HSJ, Sud M, Hebbel RP, Oettgen P, et al. (2013) A mechanistic role for DNA methylation in endothelial cell (EC)-enriched gene expression: relationship with DNA replication timing. Blood 121:3531-3540.

Strachan FE, Spratt JC, Wilkinson IB, Johnston NR, Gray GA, and Webb DJ (1999) Systemic blockade of the endothelin-B receptor increases peripheral vascular resistance in healthy men. Hypertension 33:581-585.

Suzuki T and Yamamoto M (2015) Molecular basis of the Keap1-Nrf2 system. Free Radic Biol Med 88 (Pt B):93-100.

Wang H, Liu H, Jia Z, Olsen C, Litwin S, Guan G, and Yang T (2010) Nitro-oleic acid protects against endotoxin-induced endotoxemia and multiorgan injury in mice. Am J Physiol Renal Physiol 298:F754-F762.

Woodcock SR, Bonacci G, Gelhaus SL, and Schopfer FJ (2013) Nitrated fatty acids: synthesis and measurement. Free Radic Biol Med 59:14-26.

Yanagisawa M, Kurihara H, Kimura S, Tomobe Y, Kobayashi M, Mitsui Y, Yazaki Y, Goto K, and Masaki T (1988) A novel potent vasoconstrictor peptide produced by vascular endothelial cells. Nature 332:411-415.

Zhang DD and Hannink M (2003) Distinct cysteine residues in Keap1 are required for Keap1-dependent ubiquitination of Nrf2 and for stabilization of Nrf2 by chemopreventive agents and oxidative stress. Mol Cell Biol 23:8137-8151.

Zhang J, Villacorta L, Chang L, Fan Z, Hamblin M, Zhu T, Chen CS, Cole MP, Schopfer FJ, Deng CX, et al. (2010) Nitro-oleic acid inhibits angiotensin II-induced hypertension. Circ Res 107:540-548.

Zhang X, Kazerounian S, Duquette M, Perruzzi C, Nagy JA, Dvorak HF, Parangi S, and Lawler J (2009) Thrombospondin-1 modulates vascular endothelial growth factor activity at the receptor level. FASEB $J$ 23:3368-3376.

Address correspondence to: Anna-Liisa Levonen, A.I. Virtanen Institute for Molecular Sciences, University of Eastern Finland, 70150 Kuopio, Finland. E-mail: anna-liisa.levonen@uef.fi 